Krzysztof Maliszewski*

Katowice

\title{
Szaleństwo niemożliwego versus przepracowanie - przebaczenie jako paradoksalny mechanizm rozwojowy
}

\section{Ciemne pokłady nieprzebaczenia (wprowadzenie)}

Przebaczenie to jedno z kluczowych egzystencjalnych doświadczeń związanych z rozwojem, dojrzałością, kształtowaniem charakteru, etycznością i aż dziw, że tak rzadko jest w pedagogice podejmowane ${ }^{1}$. Na pewno zasługuje na baczniejszą uwagę, jako że w grę wchodzą tu procesy z głębi tożsamości.

Poczucie krzywdy jest doznaniem powszechnym. Osobiste urazy, społecznie nabyte uprzedzenia, historyczne obciążenia sprawiają, że aura nieprzebaczenia staje się zewnętrznym i wewnętrznym środowiskiem życia. Konkretne zło, z jakim co rusz mamy do czynienia, albo je wyrządzając, albo padając jego ofiarą, przemija aktowo, lecz jego trujące konsekwencje

* Dr hab. Krzysztof Maliszewski jest kierownikiem Zakładu Podstaw Pedagogiki i Historii Wychowania w Instytucie Pedagogiki Uniwersytetu Śląskiego w Katowicach. Adres: Instytut Pedagogiki UŚ, ul. Grażyńskiego 53, 40-126 Katowice; e-mail: krzysztof.maliszewski@us.edu.pl.

${ }^{1}$ Do nielicznych należy artykuł: Katarzyna Szymala, „Przebaczenie jako działanie. O znaczeniu tego, co nieprzewidywalne dla edukacji”, Parezja 1 (2015): 103-116; sam też podejmowałem temat w eseju Powrót syna marnotrawnego - pedagogiczne laboratorium przebaczenia. Por. Krzysztof Maliszewski, Pedagogika na pograniczu światów. Eseje z cyklu „Medium Mundi” (Katowice: Wydawnictwo Uniwersytetu Śląskiego, 2015), 153-178. 
odkładają się w naszej pamięci, emocjach, wyobraźni i decyzjach. Możemy powiedzieć, że żyjemy na złożach nieprzebaczenia ${ }^{2}$. Odwety - większe i mniejsze, od okrucieństwa po nieprzyjazne słowo - to ludzka codzienność. Tadeusz Sławek tak opisuje tę kondycję: „A tu kamienie już wyrywają się do lotu z gorliwych rąk. Zapalczywe ramiona ciągną już liny podnoszące krzyże. Czy to z dala od gwarnych ulic, czy na rynkach słonecznych wypełnionych tłumem, wszędzie przemykają cienie tego, co najgorsze, a co zamknięte w nas jak drucik w żarówce"3.

Poczucie krzywdy może człowieka uwięzić, jednocześnie „rozżarzając" w nim chęć zemsty (w efekcie eskalując cierpienie), wzmacniając alibi bezradności (w postaci odmowy rozwoju na zasadzie: „Jestem taki przez was i nic nie poradzę") oraz utwierdzając niezdolność do adekwatnego reagowania aksjologicznego (złudzenie lub nawet ślepotę na wartości zgodnie $\mathrm{z}$ mechanizmem resentymentu - duchowego samozatrucia urazą na bazie nieprzebaczenia - odsłoniętym przez Maxa Schelera ${ }^{4}$ ). Timothy Radcliffe trafnie uchwycił jedno z podstawowych zagrożeń rozwoju moralnego: „Istnieje pokusa, by doznaną krzywdę uczynić centrum własnej tożsamości"`. Właśnie dlatego, że w grę wchodzą tu: wolność, dobro, motywacja rozwojowa, wrażliwość aksjologiczna, filary krystalizacji i rekonstrukcji tożsamości, uważam przebaczenie za jedno z najważniejszych - a dotąd niedocenianych - zagadnień pedagogicznych.

Trzeba przyznać, że kwestia jest wyjątkowo nieuchwytna, subtelna i złożona. Przebaczenie dotyka głębokich i drażliwych kwestii sumienia, od których w dużej mierze zależy obraz samego siebie i poczucie własnej wartości, a zatem o których ludzie mówią niechętnie, nieporadnie albo mistyfikująco, a często sami nie mają w nich dostatecznego rozeznania. Te wersje nauk o wychowaniu, które metodologicznie nie są wystarczająco otwarte na czerpanie z myśli filozoficznej i teologicznej oraz źródeł literackich, mają bardzo ograniczony dostęp do zjawiska.

W dodatku - jak każdej kwestii etycznej - grozi tej problematyce ryzyko sentymentalizacji. W pedagogicznych żarnach przebaczenie szybko może

2 Por. Krzysztof Czyżewski, ,Stare oczy Medei, czyli o nieprzebaczeniu”, w: Przebaczenie, red. Jacek Kurek, Krzysztof Maliszewski (Chorzów: MDK „Batory”, 2012$), 17$.

3 Tadeusz Sławek, Bogdan Mizerski, „Bez warunków wstępnych. Esej na głos i kontrabas. XVI punktów” (płyta CD), w: Przebaczenie, red. Jacek Kurek, Krzysztof Maliszewski (Chorzów: MDK „Batory”, 2012).

${ }^{4}$ Por. Max Scheler, Resentyment a moralność (Warszawa: Czytelnik, 1997), 52-53.

5 Timothy Radcliffe, Globalna nadzieja (Poznań: W drodze, 2005), 86. 
stać się latwym postulatem, lokowanym wyłącznie po pozytywnej stronie rozwoju, a bez dostrzegania pułapek i złożonych powiązań. Nie bez powodu Aleksandra Kunce upomina się o ,przywrócenie godności nieprzebaczenia w sferze edukacji" ${ }^{\prime}$. Przebaczeniu grozi ideologiczne zawłaszczenie, ale także automatyzm społecznej cnoty:

Imperatyw wybaczenia wypracowuje sprawny mechanizm darowania win. Upowszechnia wiedzę, że nie ma dobrej wspólnoty bez przebaczenia, co potem jest powtarzane we wszystkich sferach społecznych, również w pedagogicznych wykładniach. To proces społecznej edukacji: „wybacz”, „przeproś”, ,pogódź się, bo prosi”. Imperatyw wybaczenia jest już taką nobilitacją dla przebaczającego, że staje się niekwestionowaną wartością społeczną ${ }^{7}$.

Jednym z celów, jaki sobie tu obieram, jest pokazanie dialektycznych napięć tkwiących w zachodniej tradycji ujmowania przebaczenia, z myślą o edukacyjnej złożoności strategii rozumienia i praktykowania tej kategorii. Innym zadaniem tekstu jest zwrócenie uwagi na powagę oraz newralgiczność tematu, który sięga sedna procesów wychowawczych. Przebaczenie jest człowieczym sposobem - chociaż zapewne przeciwnym ludzkiej naturze w potocznym znaczeniu, czyli naturze pamiętliwej i do wendety skorej -konfrontacji ze złem moralnym, $\mathrm{z}$ destrukcyjnymi mocami relacji międzyludzkich, które cierpienie i zastój śmiertelny niosą. A - przypomnijmy - Sergiusz Hessen rozbudzanie wewnętrznych sił życia, przezwyciężanie samotności i śmierci duszy miał za tajemnicę prawdziwego wychowania ${ }^{8}$.

\section{Niewybaczalne}

Przebaczenie może wydawać się kwestią nieproblematyczną, gdy myślimy o krzywdach ,zwyczajnych” - przykrych bądź szkodliwych niedopatrzeniach, drobnych złośliwościach, szkodach materialnych, obelgach, waśniach, nawet wielu upokorzeniach płynących z rywalizacji czy zawiści etc. Wtedy przebaczenie - jako rezygnacja $\mathrm{z}$, baczenia” w sensie wypuszczenia

${ }^{6}$ Aleksandra Kunce, „O kulturze nieprzebaczania. Radykalizacja lokalności”, w: Przebaczenie, red. Jacek Kurek, Krzysztof Maliszewski (Chorzów: MDK „Batory”, 2012), 28.

7 Tamże, 29.

${ }^{8}$ Por. Sergiusz Hessen, O sprzecznościach i jedności wychowania (Warszawa: Wydawnictwo ,Żak”, 1997), 171-172. 
drugiego z kleszczy gniewu i odwetu - wydaje się najlepszym i oczywistym wyjściem, powstrzymującym nakręcanie społecznej spirali odpłaty oraz oczyszczającym wewnętrznie ofiarę z tłumionych negatywnych nastawień.

W wielu wypadkach mamy jednak do czynienia $\mathrm{z}$ nadmiarem zła, z jego - jak to ujmuje Paul Ricoeur - „nieznośną nadwyżką”. Okrucieństwo i skrajna podłość nie stanowią tylko naruszenia reguł, lecz wstrząsają do głębi. Zło w skrajnych - co nie znaczy rzadkich - przypadkach może oznaczać zupełne zerwanie ludzkiej więzi, może być wyrazem demonicznego pragnienia „pozostawienia drugiego człowieka na pastwę porzucenia”. Istnieje zło radykalne, którego konsekwencji nie można odwrócić, a jego ciemnej pasji oswoić. Jak pisze Ricoeur, relacjonując teologię Karla Bartha: „Należy pomyśleć nicość niechętną Bogu, nicość nie tylko ułomności i braku, lecz zepsucia i zniszczenia"10. Myśląc o Zagładzie, torturach, cierpieniu dzieci etc., chciałoby się nie tylko zwrócić bilet wstępu do nieba, ale zapaść w ciemność, a już na pewno użyć z kamienną desperacją frazy Thomasa Stearnsa Eliota: „Po takiej wiedzy - jakież wybaczenie?”11.

Emmanuel Lévinas akcentował powagę, z jaką judaizm traktuje zbrodnię i krzywdę, oddalając pokusę łatwego pojednania oraz unieważnienia dokonanego zła: „I niewątpliwie wielkość Starego Testamentu polega na tym, że pozostaje on czuły na przelaną krew, że nie może odmówić sprawiedliwości temu, kto domaga się pomsty, że czuje odrazę do przebaczenia udzielanego per procura" ${ }^{\prime 2}$. Z drugiej strony mamy radykalną wersję tradycji chrześcijańskiej, która głosi tajemnicę bezgranicznego przebaczenia, niezależnego od ciężaru winy i ogromu niegodziwości. Wybitnym reprezentantem tego nurtu jest teolog Wacław Hryniewicz, który tłumaczy, że niewybaczalność, wpisana na przykład w tak zwany grzech przeciw Duchowi Świętemu, to kwestia hiperboli prorockiej retoryki i illokucyjnej siły wypowiedzi, będącej radykalnym sprzeciwem wobec grzechu, a także usilnym apelem o jego porzucenie, a nie zaprzeczeniem możliwości wyzwolenia z konsekwencji radykalnie złej woli. W jego przekonaniu nie ma takiego zła, które naprawdę zasługiwałoby na nieskończony odwet: „Najwięksi okrutnicy i zbrodniarze w dziejach ziemi, choć byli sprawcami utraty życia i wielu ludzkich cierpien,

9 Paul Ricoeur, Pamięć, historia, zapomnienie (Kraków: Universitas, 2006), 611.

10 Paul Ricoeur, Zło. Wyzwanie rzucone filozofii i teologii (Warszawa: Instytut Wydawniczy PAX, 1992), 31.

11 Thomas Stearns Eliot, „Gerontion”, w: tenże, Szepty nieśmiertelności. Poezje wybrane (Kraków: Wydawnictwo Baran i Suszczyński, 2001), 99.

${ }^{12}$ Emmanuel Lévinas, Cztery lektury talmudyczne (Kraków: Oficyna Literacka, 1995), 35. 
nie mają na szczęście władzy nad życiem przyszłym swoich ofiar. Nie mogą im go odebrać. Nawet w ich przypadku nie byłoby proporcji pomiędzy skończoną, mimo wszystko, winą, a nieskończoną i wieczną karą"13.

Chociaż mamy tu do czynienia z ideą przebaczenia metafizycznego (religijnego), które jest w zasadzie przywilejem Boga i które - używając języka Hannah Arendt - jako odnoszące się do radyklanego zła, przekracza „dziedzinę spraw ludzkich”"14, pozwala ona jednak uwyraźnić napięcie tkwiące w zachodniej tradycji. Oto z jednej strony mamy głos, który powiada: krzywda otwiera otchłań, jakiej zasypać nie sposób; istnieją akty niewybaczalne, bo nie wolno przejść ponad niewyrównywalną utratą ofiar ani nie da się naprawdę oddzielić sprawcy od czynu (nie da się rozpocząć wszystkiego od nowa); ból jest prawdziwy, wybór jest prawdziwy. Z drugiej strony zaś naszą wyobraźnię buduje inny podszept: zło jest straszne i lekceważyć go nie wolno, ale miłość jest większa; przebaczenie istnieje i może wszystko wywrócić do góry nogami oraz nad przepaściami na skrzydłach przenosić, chociażby to się komuś nie potrafiło przyśnić; dar istnieje, epifania naprawdę powiększa życie.

\section{Teatr przebaczenia}

Na złożoność problematyki - oprócz filozoficzno-teologicznego napięcia między biegunem godności nieprzebaczenia i biegunem radykalnego przebaczenia - nakładają się konteksty społeczno-polityczne. Dyskurs przebaczenia opuszcza nieraz wewnętrzne (nie)terytorium sumienia i wkracza w przestrzeń publiczną. Czasami chodzi o to, co Leszek Kołakowski nazwał „wybaczeniem biurokratycznym”, czyli o rozmaite akty amnestii, w których organa państwowe różnych szczebli na podstawie przyjętych reguł odstępują od uzasadnionego prawem odwetu, a co może odbywać się bez osobistego zaangażowania jednostek i ich moralnych zasobów ${ }^{15}$. Innym razem może chodzić o ideologie, które zabiegają o przezwyciężenie rasowych, etnicznych, regionalnych, wyznaniowych - ogólnie grupowych - podziałów i tworzenie $\mathrm{w}$ ten sposób nowej rzeczywistości społeczno-politycznej. Jacques

13 Wacław Hryniewicz, Nadzieja woła głośniej niż lęk. Eseje wokół nauczania Jezusa historycznego (Kielce: Wydawnictwo Charaktery, 2016), 211.

${ }^{14}$ Por. Hannah Arendt, Kondycja ludzka (Warszawa: Fundacja Aletheia, 2000), 262.

15 Por. Leszek Kołakowski, Miniwykłady o maxisprawach. Trzy serie (Kraków: Znak, 2007), 224-225. 
Derrida pisał, że mamy współcześnie do czynienia ze swego rodzaju teatrem przebaczenia $^{16}$, w którym całe społeczności, korporacje zawodowe, reprezentanci kościołów i głowy państw proszą coraz częściej o przebaczenie. Istnieje jakaś wyraźna potrzeba, aby zwrócić się w stronę przeszłości i publicznie celebrować - szczerze, w dobrym poruszeniu lub cynicznie w doraźnym interesie - sceny samooskarżenia, skruchy i przebaczenia. Derrida sugerował, że czasami ta polityczna teatralizacja ma wręcz kompulsywny i konwulsyjny charakter (a grand colnvulsion, a frenetic compulsion), a już na pewno narażona jest na zawłaszczenie przez symulakry, rytualizmy, hipokryzję, mimikrę czy po prostu zimną kalkulację i tym samym zacieranie rzeczywistego wymiaru przebaczenia.

Publiczna pokuta - oprócz ryzyka politycznej banalizacji - budzi wątpliwości co do moralnych podstaw prośby o wybaczenie formułowanej przez następców i spadkobierców, czyli kogoś, kto osobiście nie był agresorem, i kierowanej do potomków ofiar, a zatem tych, którzy sami nie doznali krzywd. Instytucjonalne oraz ideologiczne wybaczenie wydaje się naruszać jakiś elementarny, wrażliwy rdzeń aktu przebaczenia, którego nie sposób oddzielić od indywidualnych podmiotowych rozstrzygnięć. Stąd sprzeciw wielu wobec teatru przebaczenia realizowanego per procura. Pisał Kołakowski:

Z pewnością nie możemy wybaczać w cudzym imieniu, to znaczy nie mamy prawa po prostu oświadczyć, że przestępcom, mordercom, oprawcom wybaczone są zbrodnie, które na innych ludziach, nieżyjących już, popełnili. Byłoby to ohydne przywłaszczenie sobie prawa innych pokrzywdzonych. Możemy wybaczać tylko we własnym imieniu to, co nam złego ktoś uczynił ${ }^{17}$.

Także Michaël de Saint-Cheron, uczeń Lévinasa, widział tu groźbę naruszenia praw nieżyjących - a więc tym bardziej bezbronnych - pokrzywdzonych: „Dziwne miłosierdzie, które bez skrupułów przebacza w imieniu ofiar. Można by nawet się zastanawiać, czy taka koncepcja przebaczenia jest rzeczywiście chrześcijańska. Gdzie jest napisane: będziesz przebaczał w imieniu ofiar i męczenników? Czy nie oznaczałoby to, że stawiamy kata, który dokonał skruchy, ponad ofiarę?"18.

${ }^{16}$ Por. Jacques Derrida, On Cosmopolitanism and Forgiveness (London-New York: Routledge, Taylor \& Francis e-Library, 2005), 28.

17 Kołakowski, Miniwykłady, 226-227.

18 Michaël de Saint-Cheron, Rozmowy z Emmanuelem Lévinasem (Warszawa: Wydawnictwo Aletheia, 2008), 184. 
Rzecz jasna zbiorowe akty przebaczenia mogą mieć sens odmienny niż uzurpacja przeniesionego na innych aktorów ułaskawiania przeszłości. Możemy zasadnie - jeśli zawiesimy na chwilę wątpliwości co do teatralizacjiprzebaczać zło, którego doznaliśmy przez to, że nasi bliscy - członkowie naszej wspólnoty - zostali skrzywdzeni. Wtedy jednak, jak podkreślał Kołakowski, „tylko nasze, nie zaś ich krzywdy są tym ułaskawieniem objęte" 19 . O personalizację przebaczenia upominała się także Aleksandra Kunce, która w zbiorowych apelach o pojednanie widzi przejaw politycznej poprawności i lekceważenie dramatów indywidualnych. Nie chodzi w dowartościowaniu gestu nieprzebaczenia o budowanie ,godnościowej” wspólnoty waśni i zemsty, jako że i tradycyjne kultury wendety czynią z odwetu rzecz nieosobistą - nakaz społeczny, pamięć zbiorową, rytuał. Tymczasem zawsze chodzi o konkretnego człowieka, zlokalizowane doświadczenie, indywidualną pamięć, niesymboliczny ból. Przebaczenie nie powinno ulegać ekstrapolacji na grupy społeczne, lecz zachować status gestu maksymalnie zindywidualizowanego, a wobec publicznych spektakli skruchy i ułaskawienia uruchomić trzeba krytyczne narzędzia: „Ironiczne spojrzenie winno być kierowane w stronę wspólnotowych, uniwersalnych nakazów przebaczenia, które mogą być formułowane religijnie, państwowo, korporacyjnie, kontynentalnie czy nawet planetarnie. Nieważne, czy formułuje je poeta, polityk, człowiek interesu czy spec od marketingu planetarnego" ${ }^{20}$. Ironię, o jakiej Kunce tu mówi, rozumiem nie $\mathrm{w}$ znaczeniu potocznym obśmiania, unieważnienia w złośliwym dystansie, lecz bardziej w duchu Richarda Rorty'ego - jako rezerwy chroniącej przed totalizacją, unikania jednostronności przez testowanie słownika, jakiego używamy i przypominanie, że istnieją też inne.

\section{Skrucha i szaleństwo}

Kolejna trudność, na jaką natrafiamy w zachodnim dyskursie o przebaczeniu, to kwestia dotykająca jego istoty, a odnosząca się do „(a)symetrii” działania ofiary i sprawcy w tym doświadczeniu. Oto z jednej strony mamy przekonanie, że przebaczenie nie może się dokonać, jeśli winny nie poprosi o to (chociażby „milcząco”). Lévinas w rozważaniach talmudycznych

19 Kołakowski, Miniwykłady, 227. Kołakowski właśnie w tym duchu niepolitycznego odpuszczenia własnych krzywd interpretuje słynny apel biskupów polskich do niemieckich: przebaczamy i prosimy o przebaczenie.

${ }^{20}$ Kunce, „O kulturze”, 34. 
stwierdza: „Ten, kto zawinił, musi uznać swój błąd; znieważony zaś musi zechcieć zadośćuczynić prośbie tego, który go znieważył. Co więcej: nikt nie może udzielić przebaczenia, jeśli znieważający o nie nie poprosi, jeśli winny nie będzie się starał przebłagać bliźniego"21. De Saint-Cheron potwierdza tę wykładnię: „Do przebaczenia potrzeba dwóch stron, jeśli jednej brakuje, jest ono niemożliwe. Nie da się udzielić przebaczenia wbrew sumieniu winowajcy"22. Wybaczenie może być traktowane nie jak powstrzymanie odwetu i anulowanie „długu”, jaki zaciąga sprawca naruszając moralną równowagę, lecz jako odzyskanie zaufania, normalizację i regenerację relacji. A ponieważ zaufanie jest rodzajem paktu, jego przywracanie to odtworzenie umowy, do czego potrzebne są dwie strony. Stąd wniosek, że winowajca musi żałować naruszenia norm i starać się o odzyskanie wiarygodności oraz że jednostronne przebaczenie byłoby nieautentyczne, oznaczało rodzaj protekcjonalnego skreślenia sprawcy, jako niezdolnego do zawarcia układu ${ }^{23}$.

$\mathrm{Z}$ drugiej strony mamy wielką tradycję przebaczenia bezwarunkowego z obrazem Jezusa z Nazaretu, który wybacza w chwili męki bynajmniej nie skruszonym i zreflektowanym oprawcom. I trudno tu mówić o jakimś władczym, fałszywym czy naiwnym geście, choć „odnowa zaufania i relacji” może pozostać $\mathrm{w}$ tym przypadku jedynie w sferze nadziei. O coś innego niż o powtórne zawiązanie umowy musi chodzić w tym akcie.

Jacques Derrida tłumaczył, że przebaczenie fundowane na symetrii skruchy i odpuszczenia ma na celu zawsze przywrócenie normalności - społecznej, narodowej, politycznej, psychologicznej etc. W społecznym procesie przebaczenia chodzi o pracę żałoby, terapię, ekologię pamięci, które mają doprowadzić do powtórnego zawiązania nici czasu historycznego (normalnego biegu życia), zerwanej przez traumę. Tymczasem „czyste” przebaczenie - mówi Derrida - nie powinno być w żaden sposób normal - ani normalne, ani normatywne, ani normalizujące. Ono ma charakter wyjątkowy i nadzwyczajny, i dokonuje się w obliczu „niemożliwego"24. W znaczącej formule francuskiego filozofa: „Przebaczenie przebacza tylko to, co niewybaczalne" 25 . Normalizujące wybaczenie społeczne musi utracić znaczenie tam, gdzie zbrodnia przekroczyła wszelkie ludzkie miary (jak w przypad-

${ }^{21}$ Lévinas, Cztery lektury, 25.

22 de Saint-Cheron, Rozmowy z Emmanuelem Lévinasem, 189.

${ }^{23}$ Por. John Wilson, „Dlaczego przebaczenie wymaga skruchy”, w: Filozofia moralności. Wina, kara, wybaczenie, oprac. Jacek Hołówka (Warszawa: Fundacja Aletheia, 2000), 453-455.

${ }^{24}$ Por. Derrida, On Cosmopolitanism, 31-32.

25 Tamże, 32. 
ku Zagłady), gdzie stała się niepojęta, nieodwracalna, monstrualna. Dlatego Hannah Arendt głosi - o czym wspominałem - że radykalnego zła nie można przebaczyć, bo wykracza ono poza sprawy ludzkie, z kolei Vladimir Jankélévitch powiada, jak przywołuje jego myśl Derrida: „Przebaczenie umarło w obozach śmierci” ${ }^{\prime 2}$. Chyba że uwierzymy - i to jest ścieżka, jaką obiera Derrida - że historia wybaczenia zaczyna się wraz z tym, co niewybaczalne, że przebaczenie staje się dopiero możliwe w chwili, gdy wydaje się zupełnie niemożliwe.

Jeśli wybaczam temu, kto żałuje swoich czynów, kto poprawia postępowanie i prosi o wybaczenie, dokonuję tego aktu wobec kogoś przemienionego, a zatem już innego niż winny, wobec którego stoję z możliwością przebaczenia. Nie mamy wtedy do czynienia z „czystym” przebaczeniem. W gruncie rzeczy - uważa Derrida - przebaczenie nie daje się zracjonalizować, ująć w zasady, zinstytucjonalizować, ostatecznie nawet zrozumieć; ono musi pozostać szaleństwem (a madness of the impossible $)^{27}$. Tak pojmowane przebaczenie pozostaje heterogeniczne w stosunku do polityki i prawa, nie ma nic wspólnego z pojednawczymi oraz terapeutycznymi zabiegami ekologii społecznej. Kiedy tylko sprawca i ofiara podejmują wymianę, wchodzą w układ, otwiera się możliwość zwyczajnego pojednania, ale nie niezwykłego, nieprzewidywalnego, nienaturalnego przebaczenia. „Absurdalność gestu przebaczenia zbawia absurdalność naszego żywota" - powie Tadeusz Sławek $^{28}$. A Jacques Derrida zaznaczy, że tej szalonej, nadmiarowej, hiperbolicznej wizji przebaczenia etycznego potrzebujemy, aby naprawdę zmieniać politykę i zmieniać prawo ${ }^{29}$.

\section{Dialektyka przebaczenia}

W narracjach, które przedstawiłem, dochodzą do głosu dwie różne logiki kulturowe - „logika równoważności” (zatroskana o sprawiedliwość, adekwatne traktowanie strat i bólu, normalizację naruszonych złem relacji) oraz „logika nadmiaru” (eksplodująca nieprzewidywalnym darem, absurdalnie miłująca, umożliwiająca niemożliwe).

\footnotetext{
26 Tamże, 37.

27 Tamże, 39.

28 Sławek, Mizerski, „Bez warunków”.

29 Por. Derrida, On Cosmopolitanism, 59.
} 
Rzecz w tym, że obydwie są nam potrzebne i to w antagonistycznej relacji, w jakiej funkcjonują. Pokazał to Paul Ricoeur, uznając, że trzeba dostrzegać niezgodę między logiką nadmiaru a logiką równoważności, a jednocześnie widzieć „chwiejną równowagę” między nimi ${ }^{30}$. Formy wielkodusznego, nadmiarowego, niezrównoważonego - dodajmy wprost: szalonego - zaangażowania takich postaci, jak św. Franciszek, Gandhi czy Martin Luther King, nie mogą być źródłem ogólnego prawa, nie dają się przekuć w reguły instytucjonalne, a zatem muszą być w zwyczajnym życiu społecznym korygowane przez zasady oparte na logice równoważności. Niemniej jednak symetryczna wymiana (Ricoeur pisze o tzw. złotej regule) - pozbawiona bezinteresownej energii daru - ma tendencję do osuwania się w utylitaryzm, a w konsekwencji w niszczące wspólnotę kalkulację i rywalizację.

Przebaczenie bezwarunkowe - w logice nadmiaru ufundowane - jest zaprzeczeniem pojednania wymagającego skruchy, lecz bez niego otwierałoby drogę w zwykłych sytuacjach społecznych do licznych nadużyć (braku sprawiedliwości, konserwowania patogennych sytuacji, niestwarzania okazji do realnej konfrontacji z krzywdą etc.). Z drugiej strony społeczne pojednanie - oparte na logice równoważności - nie uznaje w ogóle przebaczenia „czystego", jako że pokutę winnego traktuje jako warunek sine qua non skuteczności aktu przebaczenia, niemniej jednak bez potencjału „szaleństwa niemożliwego" takie pojednanie naraża się na mimowolne osuwanie w sferę kalkulacji i wszystkie patologie, jakie nazwaliśmy za Derridą „teatralizacją przebaczenia”. Francuski filozof pisał, że sam jest „rozdarty” między hiperboliczną tradycją bezwarunkowego, łaskawego, nieskończonego i nieekonomicznego przebaczenia udzielanego winnym ,jako winnym" a poświadczoną w wielu tekstach kultury wizją przebaczenia warunkowego udzielanego winnym, ,jako skruszonym i przemienionym" w społecznym procesie pragmatycznego pojednania. Oba te bieguny są nieredukowalne do siebie, ale pozostają też nierozerwalnie związane ${ }^{31}$.

Gdybym miał wykorzystać w opisie napięć tkwiących w doświadczeniu przebaczenia wprowadzony do teorii rozwoju przez amerykańskiego psychologa Erika H. Eriksona - a ostatnio uwypuklony na użytek humanistyki przez Lecha Witkowskiego ${ }^{32}$ - operator versus (oddający dwoiste struktury relacji przez lokalizację bieguna dynamizującego rozwój „wobec” przeciw-

${ }^{30}$ Por. Paul Ricoeur, Miłość i sprawiedliwość (Kraków: Universitas, 2010), 51.

31 Por. Derrida, On Cosmopolitanism, 51.

${ }^{32}$ Por. Lech Witkowski, Versus. O dwoistości strukturalnej faz rozwoju w ekologii cyklu życia psychodynamicznego modelu Erika H. Eriksona (Kraków: Impuls, 2015). 
stawnego, ale niezbędnego bieguna stabilizującego), ująłbym rzecz w następujący sposób: rozwój moralny człowieka zależy od dyspozycji do przebaczenia bezwarunkowego (jako energii przekraczania niemożliwości) versus terapeutycznej pracy społecznego pojednania wymagającej skruchy winowajcy (jako zabezpieczenia przed cynicznym wykorzystaniem aktu przebaczenia oraz umożliwienia przepracowywania traumy w wymianie między sprawcą i ofiarą, a tym samym normalizacji społecznych relacji). Niedobór dynamizującego pragnienia wypuszczenia $\mathrm{z}$ koła odwetu winnego bez żadnych warunków wstępnych zatrzaskuje tożsamość w poczuciu krzywdy albo zamyka ją w sferze kalkulacji ekonomicznej wymiany gestów. Z kolei niedostatek stabilizującej potrzeby przebaczenia warunkowego może oznaczać niezdolność do konfrontacji z powagą zła, akceptację niesprawiedliwości oraz marnotrawienie szans na przekształcanie stosunków społecznych. Tylko zachowanie dialektycznego napięcia tych dwóch tradycji/logik/pragnień umożliwia pełne korzystanie $\mathrm{z}$ rewitalizującej energii aktu przebaczenia.

\section{Implozja zła (zakończenie)}

Przebaczenie uważam za jeden z najważniejszych i najtrudniejszych procesów transformacyjnych (wychowawczych), jakie w człowieku zachodzą. Jego stawką jest wolność i podmiotowość jednostki. To pokazywała już Hannah Arendt w Kondycji ludzkiej, tłumacząc, że tylko poprzez emancypację od konsekwencji czynów ludzie mogą pozostać aktywnymi autorami życia - podmiotami (agents). I to właśnie zdolność wybaczania stanowi wybawienie od nieodwracalności i mechanizmu działania, umożliwiając rozpoczynanie „od nowa”. Jednak Arendt mówi tylko o wymiarze społecznym, tymczasem z pedagogicznego punktu widzenia liczy się nie tylko biegun stabilizujący i logika równoważności, ale przede wszystkim - choć nigdy w separacji - potencjał czynienia tego, co niemożliwe.

Przebaczenie w głębokim wewnętrznym wymiarze to tajemnica zdolności pokonania zla w sobie, zatrzymania wprawionego w ruch koła odwetu, zatrzymania go na własnych trzewiach. Wziąć skutki krzywdy - naturalnie skłaniające do oddania, ,re-akcji”, „wy-miotu”, rewanżu - na siebie oto dramatycznie bolesne jądro przebaczenia. W człowieku wybaczającym w przedziwny (szalony, niemożliwy) sposób zło ulega implozji, nie wydostaje się na zewnątrz, zanika.

Tkwi w tym rozwojowy paradoks. Albowiem przebaczyć znaczy dać się w jakimś sensie zniszczyć, „dotknąć” złu (nie odreagować, nie wyprowa- 
dzić ciosu), jednocześnie jednak nie pozwolić się zniszczyć bardziej (przez uwewnętrznienie kondycji ofiary i zagnieżdżenie mściwości). Przebaczenie jako akt bezwarunkowy nie oznacza reperacji zaufania i może współistnieć na płaszczyźnie psychologicznej - $\mathrm{z}$ trwałym poczuciem rozczarowania i smutku ${ }^{33}$. Przebaczenie jest przezwyciężeniem urazy, uwolnieniem sprawcy i własnego życia od odwetu, wyjściem (exodusem) z kondycji ofiary organizującej myślenie, uczucia, dążenia, wybory wokół rany i traumatycznego związku z katem. Ale jest jeszcze czymś więcej - „szaleństwem aksjologicznym". Przebaczyć to wprowadzić w egzystencję wartość tam, gdzie jest najmniej spodziewana: w relację ze sprawcą. Przebaczenie „czyste” nie stanowi społecznego procesu wymiany, ale nie jest też gestem separacji. Jego formuła została przez Paula Ricoeura uchwycona tak: ,jesteś wart więcej niż twoje czyny"34. Jeżeli ktoś skrzywdzony radykalnym złem, w sposób niewybaczalny, potrafi urzeczywistnić takie „szaleństwo", to znaczy, że życie jest otwarte... „Jeżeli można wybaczyć, to można zakwestionować wszystko: prawo, kodeksy, nawet żelazne reguły natury. Można nawet skruszyć mury pałacu i wieże świątyni. Taka jest wielka moc przebaczenia" ${ }^{35}$.

Pytania, jakie chciałoby się postawić o to, czy aktualny horyzont intelektualny pedagogiki i edukacji pozwala na wprowadzanie wychowanków w złożoność tradycji przebaczenia, w refleksyjne analizowanie niuansów i przypadków oraz w dojrzałe oscylowanie w trybie versus między jej sprzecznymi wariantami oraz co w ogóle można zrobić instytucjonalnie i samokształceniowo, aby tak ważny mechanizm rozwojowy, jakim jest przebaczenie, uczynić nieco bardziej świadomym i nieco dostępniejszym trosce pedagogicznej, muszą pozostać tu bez odpowiedzi i oczekiwać dopiero na podjęcie w szerzej zakreślonej pracy. O co może ktoś się pokusi, zwabiony wagą i niedostępnością ,szalonego tematu”...

\section{Madness of the Impossible versus the Working Through - Forgiveness in Education (Summary)}

The text draws attention to the important pedagogical issue, but rarely contemplated. Forgiveness is one of the crucial existential experiences in the development

${ }^{33}$ Por. Paul M. Hughes, „Na czym polega wybaczanie?”, w: Filozofia moralności. Wina, kara, wybaczenie, oprac. Jacek Hołówka (Warszawa: Fundacja Aletheia, 2000), 463.

${ }^{34}$ Ricoeur, Pamięć, 652.

35 Sławek, Mizerski, „Bez warunków”. 
of identity. There is a temptation to make a harm and a revenge the center of identity. The text shows the dialectical tension in Western tradition of forgiveness between the unforgivable and the radical forgiveness of everything; between a requirement of the repentance and an unconditional forgiveness; between a social reconciliation and an individual madness of the impossible, and between a logic of the equivalence and a logic of the excess. Pure forgiveness is the implosion of the evil. And this is one of the most important and most difficult contrivances of transformation of the human personality.

Key words: forgiveness; the theatre of forgiveness; radical evil; the unforgivable; duality; identity.

\section{Szaleństwo niemożliwego versus przepracowanie - przebaczenie jako paradoksalny mechanizm rozwojowy (Streszczenie)}

Tekst zwraca uwagę na istotną, ale rzadko rozważaną kwestię pedagogiczną. Przebaczenie to jedno z kluczowych egzystencjalnych doświadczeń związanych z rozwojem tożsamości. Istnieje pokusa, by krzywdę i odwet czynić centrum tożsamości. Tekst pokazuje dialektyczne napięcia zachodniej tradycji opisu przebaczenia między niewybaczalnym a radykalnym przebaczeniem wszystkiego, wymogiem skruchy a wybaczeniem bezwarunkowym, społecznym pojednaniem a indywidualnym szaleństwem niemożliwego, logiką równoważności a logiką nadmiaru. Przebaczenie „czyste” to implozja zła. A to jest jeden z najważniejszych i najtrudniejszych mechanizmów transformacji osobowości człowieka.

Słowa kluczowe: przebaczenie; teatralizacja przebaczenia; radykalne zło; niewybaczalne; dwoistość; tożsamość.

\section{Bibliografia}

Arendt, Hannah. Kondycja ludzka. Warszawa: Fundacja Aletheia, 2000.

Czyżewski, Krzysztof. „Stare oczy Medei, czyli o nieprzebaczeniu”. W: Przebaczenie, red. Jacek Kurek, Krzysztof Maliszewski, 17-24. Chorzów: MDK „Batory", 2012.

Derrida, Jacques. On Cosmopolitanism and Forgiveness. London-New York: Routledge, Taylor \& Francis e-Library, 2005. 
Eliot, Thomas Stearns. „Gerontion”. W: tenże, Szepty nieśmiertelności. Poezje wybrane, 99. Kraków: Wydawnictwo Baran i Suszczyński, 2001.

Hessen, Sergiusz. O sprzecznościach i jedności wychowania. Warszawa: Wydawnictwo „Żak”, 1997.

Hryniewicz, Wacław. Nadzieja woła głośniej niż lęk. Eseje wokół nauczania Jezusa historycznego. Kielce: Wydawnictwo Charaktery, 2016.

Hughes, Paul M. „Na czym polega wybaczanie?”. W: Filozofia moralności. Wina, kara, wybaczenie, oprac. Jacek Hołówka, 457-468. Warszawa: Fundacja Aletheia, 2000.

Kołakowski, Leszek. Miniwykłady o maxisprawach. Trzy serie. Kraków: Znak, 2007. Kunce, Aleksandra. „O kulturze nieprzebaczania. Radykalizacja lokalności”. W: Przebaczenie, red. Jacek Kurek, Krzysztof Maliszewski, 25-34. Chorzów: MDK „Batory”, 2012.

Lévinas, Emmanuel. Cztery lektury talmudyczne. Kraków: Oficyna Literacka, 1995. Maliszewski, Krzysztof. Pedagogika na pograniczu światów. Eseje z cyklu „Medium Mundi”. Katowice: Wydawnictwo Uniwersytetu Śląskiego, 2015.

Radcliffe, Timothy. Globalna nadzieja. Poznań: W drodze, 2005.

Ricoeur, Paul. Miłość i sprawiedliwość. Kraków: Universitas, 2010.

Ricoeur, Paul. Pamięć, historia, zapomnienie. Kraków: Universitas, 2006.

Ricoeur, Paul. Zło. Wyzwanie rzucone filozofii i teologii. Warszawa: Instytut Wydawniczy PAX, 1992.

Saint-Cheron, Michaël de. Rozmowy z Emmanuelem Lévinasem. Warszawa: Wydawnictwo Aletheia, 2008.

Scheler, Max. Resentyment a moralność. Warszawa: Czytelnik, 1997.

Sławek, Tadeusz, Bogdan Mizerski. „Bez warunków wstępnych. Esej na głos i kontrabas. XVI punktów" (płyta CD). W: Przebaczenie, red. Jacek Kurek, Krzysztof Maliszewski. Chorzów: MDK „Batory”, 2012.

Szymala, Katarzyna. „Przebaczenie jako działanie. O znaczeniu tego, co nieprzewidywalne dla edukacji”. Parezja 1 (2015): 103-116.

Wilson, John. „Dlaczego przebaczenie wymaga skruchy”, w: Filozofia moralności. Wina, kara, wybaczenie, oprac. Jacek Hołówka, 453-455. Warszawa: Fundacja Aletheia, 2000.

Witkowski, Lech. Versus. O dwoistości strukturalnej faz rozwoju w ekologii cyklu życia psychodynamicznego modelu Erika H. Eriksona. Kraków: Impuls, 2015. 